\title{
Peran Konflik Peran Ganda Terhadap Spiritualitas Di Tempat Kerja Pada Guru Wanita Sekolah Dasar Negeri (SDN) Di Jakarta
}

\author{
Devi Jatmika, Syanthi Dewi Utomo \\ Program Studi Psikologi Universitas Bunda Mulia \\ email: dephey@gmail.com
}

\begin{abstract}
Artikel INFO
Diterima:30 Sept 2019

Direvisi :17 Okt 2019

Disetujui: 04 Des 2019

DOI:

http://dx.doi.org/10.24014/ jp.v14i2.7794
\end{abstract}

\begin{abstract}
Abstrak
Profesi sebagai seorang guru SD memiliki tantangan bagi guru wanita yang harus berperan sebagai pendidik yang baik dan berkualitas begitupula dengan perannya sebagai seorang ibu dan istri di rumah. Pekerjan guru memiliki tanggung jawab moril untuk mendidik siswa dan harus membuat materi ajar serta administrasi lainnya. Sehingga, penting bagi seorang guru agar tetap bertahan dalam pekerjannya dengan mampu memiliki spiritualitas kerja. Tujuan penelitian ini adalah untuk menganalisa peran konflik peran ganda terhadap spiritualitas di tempat kerja. Penelitian ini menggunakan metode penelitian kuantitatif. Pengumpulan data dilakukan dengan menyebarkan kuesioner konflik peran ganda dan spiritualitas di tempat kerja. Sampel dalam penelitian ini guru wanita SDN berjumlah 394 orang di Jakarta. Teknik analisa yang digunakan terdiri dari analisa deskriptif dan regresi. Hasil diperolah konflik peran ganda berada dalam kategori rendah, sedangkan spiritualitas di tempat kerja di kategori tinggi. Konflik peran ganda memiliki pengaruh negatif sebesar $17.2 \%$ terhadap spiritualitas di tempat kerja. Ketiga dimensi dari konflik peran ganda berhubungan signifikan terhadap spiritualitas di tempat kerja. Strain based conflict merupakan dimensi konflik peran ganda berhubungan signifikan yang paling memprediksi spiritualitas di tempat kerja diikuti dengan behavior based conflict dan time based conflict.
\end{abstract}

Kata Kunci: konflik peran ganda; spiritualitas di tempat kerja; guru wanita.

\section{The Role of Work- Family Conflict on Spirituality at Work of Female Teachers in Public Elementary School in Jakarta}

\begin{abstract}
As a primary school teacher has got challenges for women teachers who have a role as good and qualified educators at the same time their role as a mother and wife at home. Teachers' job have moral responsibility to educate their students and have to create teaching materials and doing other administration. Therefore, it is important for a teacher to able to adopt spirituality at work. The aim of this research was to analyse the influence of work family conflict with spirituality at work. This study used quantitative research methods. Data was collected by distributing work family conflict questionnaire and spirituality at work. The respondents of this research was 394 female teachers in public schools. The data analysis was done by using descriptive analysis and regression. Results revealed work family conflict was in low category, meanwhile spirituality at work was in high category. The amount of work family conflict has effected spirituality at work was $17.2 \%$. Strain based conflict was the most significant predictor of spirituality at work followed by behavior based conflict and time based conflict.
\end{abstract}

Keywords: work family conflict; spirituality at work; female teachers

\section{Pendahuluan}

Pekerjaan sebagai seorang guru membutuhkan keinginan dan panggilan jiwa individu untuk mengabdi. Pekerjaan menjadi seorang guru bukanlah hal yang mudah karena tanggungjawab moril yang diemban sebagai seorang guru. Saat ini, pemerintah sudah menetapkan kebijakan yang tertera pada Undang- Undang Kepegawaian dan Undang - Undang Ketenagakerjaan dimana setiap guru harus bekerja 40 jam per minggu. Berdasarkan PP nomor 74/2008 tentang guru pasal 52 ayat (1), beban kerja guru adalah merencakan pembelajaran, melaksanakan pembelajaran, menilai hasil pembelajaran, membimbing dan melatih peserta didik serta melaksanakan tugas tambahan yang melekat 
pada kegiatan pokok ("Beban Kerja Guru", 2016).

Disamping beban kerja tersebut, menjadi guru pun tidak akan terlepas dari masalah akademik anak didiknya (Imran, 2015), harus bisa memahami karakter dari setiap anak sehingga ia dapat memahami anaknya dan dapat membantu dalam proses mendidik (Ansar, 2016). Guru juga dituntut untuk terus mengikuti perkembangan ilmu pengetahuan dan teknologi dan ia juga harus mematuhi aturan - aturan yang berlaku (Arifin, 2013). Sebagai kesimpulan, menjadi seorang guru merupakan suatu profesi yang memerlukan seperangkat kompetensi baik kompetensi profesional, pedagogik, pribadi maupun kompetensi sosial (Arifin, 2013).

Data Dirjen Peningkatan Mutu Pendidikan dan Tenaga Pendidikan Kementerian Pendidikan menunjukkan bahwa jumlah guru di Indonesia mencapai 2,92 juta dengan guru honorer mencapai 90.000 orang (Iskandar, 2013). Dengan jumlah guru terbanyak di Indonesia, 36.163 guru di Jakarta diantaranya adalah guru sekolah dasar, sebanyak 17.681 diantaranya adalah guru sekolah menengah pertama dan 10.459 diantaranya adalah guru sekolah menengah atas (Kementrian Pendidikan dan Kebudayaan, 2017). Guru sekolah dasar terutama sekolah dasar negeri memiliki beban kerja yang paling sulit karena selain sebagai guru kelas, ditambah pula jam kerja wajib 24 jam dalam seminggu yang mana guru harus mengajarkan ekstrakurikuler serta adanya tuntutan untuk melakukan tugas-tugas administrasi seperti pertanggungjawaban dana BOS (Bantuan Operasional Sekolah), BOP (Biaya Operasional Pendidikan), dan RKAS (Rencana Kerja Anggaran Sekolah).

Pekerjaan sebagai seorang guru untuk memperkaya dan mendorong kualitas positif murid dan karakter mereka, menunjukkan arah yang positif untuk pikiran siswa, sehingga penting sebagai seorang guru untuk mengaktualisasikan diri dalam pekerjaannya. Menurut Abraham Maslow (dalam Butts, 1999) dalam hierarki kebutuhan disebutkan bahwa bekerja membantu memenuhi keberlangsungan kebutuhan personal, kebutuhan rasa aman harga diri, dan kebutuhan ego yang kemudian pekerja akan cenderung berorientasi pada aktualisasi diri yang lebih tinggi dan kebutuhan spiritual.

Ashmos dan Duchon (2000) menggambarkan spiritualitas dalam kehidupan pribadi adalah pengalaman manusia dalam pencarian makna dan tujuan merupakan hal yang utama dan hidup dalam harmoni dengan orang lain dipandang sebagai sesuatu yang sangat penting meskipun harus bertentangan dengan arus nilai-nilai lain yang cenderung memacu perolehan materi. Spiritualitas pada guru ditemukan berhubungan dengan keterlibatannya dalam bekerja dan kemudian berdampak pada perilaku dan kinerjanya di organisasi (Ke, Zhang, Yan \& Fu, 2017). Boone, Fite, Reardon (2010), seorang guru yang memiliki spiritualitas akan berupaya untuk meningkatkan pengetahuannya sebagai guru, pengetahuan interpersonal yang berkaitan dengan hubungannya dengan siswa dan komunitas pendidikannya, dan pengetahuan intra personal yaitu pengetahuan guru tentang diri dan komitmen atas kepedulian dan etos kerjanya untuk terus belajar.

Spiritualitas di tempat kerja tidak berhubungan dengan agama atau internalisasi nilai-nilai keyakinan tertentu kepada orang lain, namun tentang karyawan yang memahami diri mereka sebagai makhluk spiritual dengan jiwa yang perlu diperkaya dalam dunia kerja. Kinjerski (2013) dari hasil penelitian pengukuran spiritualias di tempat kerja, mengemukakan empat dimensi dari spiritualitas di tempat kerja: 1). Engaging work (EW) adalah dimensi kognitif yang dikarakteristikan sebagai perasaan otentik, kesadaran sejalannya nilai-nilai yang dimiliki dengan pekerjaannya, keyakinan bahwa dirinya melakukan pekerjaan yang memiliki nilai tujuan yang lebih tinggi; 2). Sense of community (SoC) adalah dimensi interpersonal yang dikarakteristikkan dengan perasaan memiliki koneksi atau hubungan dengan orang lain dan tujuan bersama; 3). Spiritual connection (SpC) adalah dimensi kehadiran spiritual, perasaan keterhubungan dengan sesuatu yang lebih besar dari dirinya; 4). Mystical experience (ME) adalah sensasi fisik, pengalaman afeksi dan sempurna, transendensi, merasa hidup di saat ini.

Penelitian Milliman, Czaplewski dan Ferguson (2003), yang mengukur dimensi spiritualitas yaitu perasaan bermakna dalam pekerjaan, perasaan terhubung dengan komunitas, dan penegakan nilainilai menemukan bahwa spiritualitas yang dimiliki individu berhubungan dengan komitmen organisasi, berkorelasi negatif dengan intensi untuk keluar, korelasi positif dengan kepuasan kerja, keterlibatan kerja dan meningkatkan perasaan harga diri dalam organisasi. Yogatama dan Widyarini (2015) 
dalam penelitiannya mengenai faktor-faktor spiritualitas di tempat kerja dalam konteks organisasi bisnis di Indonesia, diketahui dua faktor esensial yaitu faktor rasa bertujuan dan bermakna dalam pekerjaan dan faktor perasaan nyaman, bebas dan mengalami perkembangan pribadi didukung oleh kepedulian organisasi untuk mempertemukan kepentingan organisasi dengan kepentingan individu dan memberdayakan karyawan.

Dalam teori self-determination (Ryan \& Deci, 2000) individu berupaya untuk memuaskan tiga kebutuhan intrinsik yaitu autonomy, competence dan relatedness. Ketiga kebutuhan intrinsik ini tercermin dalam spiritualitas di tempat kerja dan sejalan dengan nilai-nilai organisasi (Milliman et. al, 2003), sehingga orang-orang dengan keterhubungan (connectedness) yang semakin tinggi akan menjadi individu yang lebih positif dan mencapai tujuan organisasi. Mengajar adalah profesi yang menekankan motivasi intrinsik dan rasa terpanggil yang membuat guru tetap menjalankan perannya. Penelitian Rajappan, Nair, Priyadarshini dan Sivakumar (2017) menemukan spiritualitas kerja guru SMP dan job embededdeness berkorelasi signifikan, semakin tinggi spiritualitas kerja maka guru semakin bekeinginan untuk tetap bertahan di tempat kerja. Sehingga, pengalaman spiritualitas di tempat kerja pada guru merupakan hal yang penting karena guru akan lebih termotivasi, mampu berkontribusi yang terbaik untuk sekolah, anak didiknya dan dirinya sendiri.

Dari 36.163 guru sekolah dasar di Jakarta, 26.023 orang diantaranya adalah wanita (Kementrian Pendidikan dan Kebudayaan, 2017). Survei yang dilakukan oleh Tanudjaja (2013) kepada 30 orang guru di salah satu SMP di Surabaya, para guru wanita pernah mengalami kehilangan gairah untuk mengajar dan ini mengindikasikan kurangnya dedikasi kepada profesinya sebagai seorang guru. Sejumlah 23 guru merasa bosan dan jenuh dengan tugas-tugasnya, merasa waktu mengajar berjalan lama, ingin segera pulang ke rumah dan tidak senang jika harus lembur. Aboobaker, Edward dan Zakkariya (2019) menemukan konflik peran ganda memediasi hubungan antara makna kerja dan sense of community yang merupakan unsur dari spiritualitas dengan intensi guru untuk tetap bekerja.

Penelitian yang berkonsentrasi pada perbedaan gender mengungkapkan bahwa wanita lebih rentan untuk mengalami konflik peran ganda dan tingkatnya lebih tinggi apabila dibandingkan dengan pria. Hal ini disebabkan karena peran pria dalam keluarga yang lebih fleksibel apabila dibandingkan dengan peran wanita (Lo dalam Sabuhari dan Soleman, 2016). Penelitian yang dilakukan oleh Richter, Schraml, dan Leineweber (2014) diketahui baik pria maupun wanita dapat mengalami konflik peran ganda, namun perempuan dilaporkan lebih merasakan kelelahan emosi daripada pria. Wanita juga melaporkan konflik peran ganda yang tinggi lebih banyak daripada pria dikarenakan distribusi tanggungjawab rumah tangga dan pengasuhan anak yang tidak seimbang. Konflik peran ganda ini dapat memberikan konsekuensi yang berat bagi wanita karena di satu sisi, wanita ingin membantu suaminya dalam mencari nafkah namun di sisi lain, wanita juga harus memenuhi tanggung jawabnya sebagai istri dan ibu (Apollo \& Cahyadi, 2012).

Menurut Chusniatun, Kuswardhani dan Suwandi (2014), dalam urusan karir, wanita mendasari diri mereka dengan pertimbangan - pertimbangan yang berhubungan dengan kodratnya sebagai wanita dan juga keluarga. Hal ini akan berpengaruh apabila wanita tersebut sudah menikah dan memiliki anak karena pekerjaannya dapat memicu timbulnya dilema peran antara pekerjaan dan keluarganya (Chusniatun, Kuswardhani dan Suwandi, 2014).

Beratnya tuntutan guru sekolah dasar di sekolah serta adanya tuntutan di rumah, dapat menimbulkan adanya tekanan bagi guru tersebut (Julianty \& Prasetya, 2016). Maka dari itu, untuk dapat menyelesaikan tuntutan dalam pekerjaannya, setiap guru diharapkan dapat mengatur keseimbangan peran antara pekerjaan rumah tangga dan tugas profesi guru (Chusniatun, Kuswardhani \& Suwandi 2014). Ketidakmampuan guru dalam mengatur keseimbangan peran berpotensi untuk menimbulkan konflik diantara kedua peran atau yang kerap kali disebut sebagai konflik peran ganda (Julianty \& Prasetya, 2016). Seseorang dapat dikatakan mengalami konflik peran ganda ketika orang tersebut mengalami suatu ketegangan dalam menjalani peran pekerjaan dan peran dalam keluarganya (Almasitoh, 2011).

Konflik peran ganda merupakan konflik multi dimensional yang mengacu pada konflik - konflik seperti time based, strain based atau behavior based (Stephens \& Sommer dalam Fields, 2002). Time based conflict 
mendeskripsikan situasi dimana ada sebuah elemen temporal yang menyebabkan konflik, seperti bekerja sampai larut, tidak makan malam bersama keluarga, mengurus anak dan terlambat bekerja. Konflik kedua adalah strain based conflict yang terjadi ketika tuntutan psikologis di salah satu domain mencampuri tanggung jawab pada domain lainnya. Konflik terjadi bila seseorang pekerja mengalami kejadian traumatik di kantor, saat di rumah ia tidak dapat berkonsentrasi sehingga tidak dapat berkomunikasi dengan baik bersama keluarganya dan terjadi kelelahan mental. Konflik yang terakhir adalah behavior based conflict yang terjadi ketika perilaku yang tidak tepat pada satu domain terbawa ke domain lainnya. Contohnya, jika seorang pekerja dituntut untuk menjadi seseorang dengan otoritas dan selalu mengarahkan orang lain dalam pekerjaannya, ketika di rumah ia tetap menunjukkan perilaku otoritas tersebut.

Pekerjaan sebagai seorang guru dianggap sesuai dengan wanita karena mereka dapat mengalokasikan waktu dan peran untuk keluarga. Cinnamon dan Rich (2005) mengemukakan bahwa profesi guru dianggap cocok untuk wanita karena tidak memiliki beban kerja yang terlalu banyak dan di waktu yang sama, wanita dapat berperan di tempat kerja dan keluarga dengan level konflik yang rendah. Akan tetapi, berbagai studi menunjukkan sebagian besar guru wanita tidak dapat memisahkan peran professional dan peran di keluarga dengan efektif (Cinnamon \& Rich, 2005). Dalam menjalankan profesinya sebagai guru, menyeimbangkan peran sebagai guru dan ibu bukanlah hal yang mudah karena ia harus berperan sebagai ibu dan guru yang baik. Ketika harus berperan sebagai ibu dan guru yang baik menimbulkan konflik pada guru wanita.

Dengan adanya konflik peran ganda dan tuntutan pekerjaan, individu seringkali berusaha mencari kebermaknaan dan keterhubungan diri dengan pekerjaannya. Spiritualitas di tempat kerja memiliki peran agar para guru mampu merasakan makna dari pekerjaannya. Berdasarkan paparan di atas, hipotesis dalam penelitian ini adalah terdapat pengaruh negatif dari konflik peran ganda terhadap spiritualitas di tempat kerja pada guru wanita tingkat SD.

\section{Metode}

\section{Desain}

Penelitian ini termasuk dalam tipe penelitian eksploratif, karena eksploasi di area penelitian ini masih sedikit dan belum ditemukan penelitian serupa di negara Asia. Desain yang digunakan dalam penelitian ini adalah penelitian kuantitatif. Penelitian ini termasuk dalam jenis penelitian noneksperimental, dimana peneliti tidak memanipulasi atau menciptakan variabelvariabel yang akan diukur. Dalam penelitian non-eksperimental, variabel-variabel telah ada dan sudah terberi pada subjek penelitian. Dalam penelitian ini, peneliti menggunakan pendekatan kuantitatif karena memungkinkan peneliti untuk mengukur respon dari banyak orang dengan sejumlah pernyataan (Gravetter \& Forzano, 2012).

\section{Partisipan}

Populasi guru SD berjenis kelamin wanita di Jakarta dengan jumlah 26.036 orang (Kemdikbud, 2017). Sampel yang digunakan dalam penelitian ini adalah guru SD Negeri yang telah berkeluarga di Jakarta. Jumlah sampel yang akan digunakan dalam penelitian ini adalah sebanyak 394 orang guru SD Negeri yang sudah menikah di Jakarta. Karakteristik sampel yang digunakan dalam penelitian ini adalah guru wanita yang berusia 20-60 tahun, sudah menikah dalam arti menyandang status menikah dan sudah memiliki anak dan merupakan guru tetap. Teknik sampling yang digunakan dalam penelitian ini adalah probability sampling methods dengan jenis cluster sampling. Cluster sampling merupakan teknik sampling dimana peneliti menentukan kluster dari kelompok yang sudah ada dan peneliti memilih secara acak kelompok sampel yang akan digunakannya (Gravetter dan Forzano, 2012). Kluster dimaksud dalam penelitian ini adalah Sekolah Dasar Negeri yang berada di lima wilayah di Jakarta. Sampel penelitian mewakili dari populasi guru SDN di lima wilayah yaitu Jakarta Utara, Jakarta Barat, Jakarta Timur, Jakarta Selatan dan Jakarta Pusat. Data SD negeri diperoleh dari situs Dinas Pendidikan yang menyediakan alamat lengkap beserta informasi mengenai sekolah tersebut. 


\section{Pengukuran}

Instrumen konflik peran ganda yang digunakan dalam penelitian dibuat berdasarkan dimensi-dimensi work-family conflict. Greenhaus dan Beutell (1985) membagi konflik peran ganda kedalam 3 dimensi yaitu time based conflict, strain based conflict, dan behavior based conflict. Ketiga dimensi ini terdapat di dalam 19 butir pernyataan favorable dan unfavorable yang terbagi atas 4 pernyataan pada dimensi time based conflict, 8 pernyataan pada dimensi strain based conflict dan 7 pernyataan pada dimensi behavior based conflict. Setiap pernyataan dalam instrumen ini pun diacak untuk mengetahui konsistensi jawaban dari responden penelitian. Uji tryout untuk mengetahui validitas dan reliabilitas alat ukur dilakukan kepada kepada 40 orang guru SDN. Butir valid adalah butir dengan nilai $r>0.3$, didapatkan sebanyak 7 butir gugur sehingga tersisa 12 butir valid dengan nilai $\alpha=0,882$. Contoh-contoh butir untuk konflik peran ganda, pada dimensi strain based conflict: "Tuntutan dalam pekerjaan menyulitkan saya untuk mempertahankan hubungan dengan pasangan dan anak-anak saya sesuai dengan keinginan saya", dimensi time based conflict: "Pekerjaan saya mengurangi banyak waktu saya untuk bersama dengan keluarga", dan dimensi behavior based conflict:"Ketika sasya mersa kesal dengan anak murid saya, saya seringkali melampiaskan kepada keluarga saya".

Instrumen spiritualitas di tempat kerja yang digunakan dalam penelitian ini adalah adaptasi dari kuesioner Spirit at Work Scale (SAWS) oleh Kinjerski \& Skrypnek (dalam Kinjerski, 2013) yang terdiri dari 18 butir terbagi dalam 4 dimensi yaitu Engaging Work (EW), Sense of Community (SoC), Spiritual Connection (SpC) dan Mystical Experience (ME). Secara keseluruhan, dimensi EW terdiri dari 7 butir, ME terdiri dari 5 butir, SpC terdiri dari 3 butir dan SoC terdiri dari 3 butir. Dimensi EW merefleksikan dimensi kognitif dari perasaan otentik, kesadaran bahwa nilai pribadi yang dimiliki sejalan dengan pekerjaan. Contoh butir dimensi EW seperti: "Saya mampu menemukan arti atau tujuan dalam pekerjaan saya". Dimensi SoC merefleksikan pengertian dimensi interpersonal, perasaan terhubung dengan orang lain dan tujuan bersama. Contoh butir dimensi SoC seperti: "Saya merasakan kepercayaan dan hubungan personal dengan rekan kerja saya." Faktor SpC, merefleksikan karakteristik dari kehadiran spiritual, perasaan terhubung atas sesuatu yang lebih besar dari diri. Contoh butir seperti: "Saya merasakan hubungan spiritual yang kuat sesuai keyakinan saya yang memiliki efek positif pada pekerjaan saya". Faktor ME merefleksikan sensasi fisik, perasaan positif dan perasaan spiritual. Contoh butir seperti: "Saya merasakan momen dalam bekerja dimana semua hal itu merupakan kebahagiaan". Pengukuran dengan 4 poin skala Likert, dengan rentang 1 (Sangat Tidak Setuju) hingga 4 (Sangat Setuju). Properti psikometri dari spirit at work scale menunjukkan konsistensi internal yang baik dengan nilai reliabilitas $\alpha=0,93$ (Kinjerski, 2013). Dalam penelitian ini setelah uji tryout diperoleh 15 butir valid dari 18 butir dengan dengan $\alpha=0,875$.

\section{Prosedur}

Pada tahap persiapan penelitian, peneliti mencari fenomena-fenomena dalam pekerjaan sebagai guru baik di tingkat SD hingga SMA untuk menemukan perbedaan beban kerja yang dirasakan oleh para guru serta melakukan interview awal kepada beberapa guru. Setelah menemukan masalah penelitian dan membuat rumusan masalah, peneliti merumuskan tujuan dari penelitian. Pencarian kajian literatur, penelitian-penelitian sebelumnya yang diperoleh buku teks, jurnaljurnal penelitian dan artikel-artikel ilmiah untuk membuat tinjauan pustaka. Setelah itu, penentuan untuk variabel operasional, sampel penelitian, teknik sampling dan instrument penelitian. Pada tahap pelaksanaan penelitian, setelah instrumen penelitian sudah dibuat akan dihitung validitas dan reliabilitas dari instrument. Kuesioner alat ukur konflik peran ganda dan spiritualitas di tempat kerja disebarkan kepada guruguru wanita SD yang sesuai dengan kriteria sampel di Jakarta. Prosedur penyebaran data dengan mendatangi langsung ke sekolahsekolah, tidak melalui kuesioner online. Peneliti menanyakan setiap guru SDN yang bekerja di sekolah tersebut kesediaannya untuk mengisi kuesioner. Responden terlebih dahulu mengisi informed consent dan menandatanganinya, barulah mengisi kuesioner. Data yang diberikan responden dijamin kerahasiaannya. Peneliti juga tidak memberikan kompensasi apapun kepada responden. Setelah data yang dibutuhkan terkumpul, peneliti melakukan analisa data, interpretasi hasil penelitian dan membuat pembahasan dari hasil penelitian. Pada bagian akhir penelitian disajikan kesimpulan dan saran penelitian.

\section{Analisis Data}

Uji asumsi yang dilakukan dalam penelitian ini adalah dengan melakukan uji normalitas menggunakan Kolmogorov Smirnov. Uji normalitas dilakukan untuk mengetahui kenormalan distribusi dari beberapa data. Data dikatakan berdistribusi normal jika menunjukkan sig ( $p$ ) >0.05 (Nisfianoor, 2009). Peneliti juga melakukan uji linearitas untuk mengetahui apakah data tergolong linear atau tidak sebagai syarat 
untuk regresi dengan uji linieritas via Anova. Jika signifikansi nilai linearity sig $(p)<0.05$, maka dapat dikatakan kedua variabel berhubungan secara linier (Widhiarso, 2010). Selanjutnya untuk melakukan analisis regresi, peneliti menggunakan model analisis regresi linier sederhana. Teknik uji multikolienaritas untuk mengetahui korelasi antarvariabel independen model regresi.

\section{Hasil}

Hasil pengambilan data diperoleh 396 subjek yang sesuai dengan kriteria penelitian. Mayoritas responden memilliki pendidikan akhir S1 (90.7\%), lama mengajar paling banyak 31-35 tahun sebagian besar berusia 51-60 tahun (36.36\%).

Tabel 1. Gambaran Demografis Responden Penelitian

\begin{tabular}{|c|c|c|}
\hline Gambaran Demografis Subjek & Frekuensi & Persentase \\
\hline \multicolumn{3}{|l|}{ Pendidikan } \\
\hline S3 & 2 & 0.5 \\
\hline $\mathrm{S} 2$ & 24 & 6.1 \\
\hline S1 & 359 & 90.7 \\
\hline D3 & 3 & 0.8 \\
\hline D2 & 6 & 1.5 \\
\hline SMA & 2 & 0.5 \\
\hline \multicolumn{3}{|c|}{ Wilayah } \\
\hline Jakarta Barat & 77 & 19.4 \\
\hline Jakarta Pusat & 83 & 23.7 \\
\hline Jakarta Selatan & 76 & 19.2 \\
\hline Jakarta Timur & 79 & 19.9 \\
\hline Jakarta Utara & 81 & 20.5 \\
\hline \multicolumn{3}{|c|}{ Lama Mengajar } \\
\hline $1-5$ tahun & 36 & 9.1 \\
\hline $6-10$ tahun & 51 & 12.9 \\
\hline 11-15 tahun & 70 & 17.7 \\
\hline 16-20 tahun & 48 & 12.1 \\
\hline 21-25 tahun & 34 & 8.6 \\
\hline 26-30 tahun & 48 & 12.1 \\
\hline 31-35 tahun & 79 & 19.9 \\
\hline $36-40$ tahun & 29 & 7.3 \\
\hline$>40$ tahun & 1 & 0.3 \\
\hline \multicolumn{3}{|c|}{ Usia } \\
\hline 21-30 tahun & 41 & 10.36 \\
\hline $31-40$ tahun & 93 & 23.48 \\
\hline $41-50$ tahun & 118 & 29.8 \\
\hline $51-60$ tahun & 144 & 36.36 \\
\hline
\end{tabular}

Gambaran statistik deskriptif konflik peran ganda dan spiritualitas di tempat kerja dari partisipan. Kategorisasi norma dengan menggunakan mean hipotetik dan mean empirik (Nisfiannoor, 2009). Kategorisasi diperoleh dengan membandingkan mean hipotetik dan mean empirik. Di tabel 2 . di bawah, konflik peran ganda tergolong kategori rendah (mean hipotetik > mean empirik), sedangkan spiritualitas di tempat kerja berada di kategori tinggi (mean empirik> mean hipotetik). 
Tabel 2. Gambaran statisik deskriptif

\begin{tabular}{cccccc}
\hline Variabel & Max & Min & SD & Mean empirik & $\begin{array}{c}\text { Mean } \\
\text { hipotetik }\end{array}$ \\
\hline Konflik peran ganda & 12 & 40 & 4.35 & 22.76 & 37.5 \\
Spiritualitas di tempat kerja & 60 & 29 & 4.87 & 50.02 & 30 \\
\hline
\end{tabular}

Hasil uji asumsi

Uji normalitas dalam penelitian ini menggunakan uji Kolmogorov- Smirnov. Hasil uji normalitas ditemukan bahwa variabel spiritualitas di tempat kerja dengan $p=0.000$ $<0.05$ dan konflik peran ganda $p=0.001<0.05$, sehingga dapat disimpulkan data berdistribusi tidak normal dengan nilai signifikasi $p<0.05$. Hasil uji linearitas ditemukan hubungan antar variabel telah memenuhi asumsi linier karena sig $(p)$ adalah $0.000(F=1.525 ; p<0.05)$.

\section{Uji regresi linier sederhana}

Daritabel3 dibawah ini, hasil menunjukkan bahwa konflik peran ganda memiliki pengaruh terhadap spiritualitas di tempat kerja $F(1$, $394)=81.977$, sig $(p)=0.000, p<0.01$ dengan nilai $R$ square $=0.172$ yang berarti terdapat pengaruh signifikan dari konflik peran ganda dengan sumbangan konflik peran ganda sebesar $17.2 \%$ sedangkan sisanya dipengaruhi oleh faktor lain.

Analisa lebih lanjut untuk mengetahui bagaimana pengaruh time based conflict, strain based conflict dan behavior based conflict terhadap spiritualitas di tempat kerja. Di tabel 3, diketahui hasil time based conflict terhadap spiritualitas di tempat kerja, $t=$ -5.364 , sig $(p)=0.000, p<0.01$ yang berarti time based conflict memprediksi spiritualitas di tempat kerja, dengan sumbangan sebesar $6,8 \%$. Pada dimensi behavior based conflict terhadap spiritualitas di tempat kerja, $\mathrm{t}=$ --4.545 , sig $(p)=0.000, p<0.01$, yang berarti behavior based conflict dapat memprediksi spiritualitas di tempat kerja, dengan sumbangan sebesar $5 \%$. Dimensi ketiga strain based conflict, $\mathrm{t}=-8.886$, sig $(p)=0.000, p<$ 0.01 sehingga dapat dikatakan dimensi strain based conflict dapat memprediksi spiritualitas di tempat kerja, dengan sumbangan variabel sebesar $16.7 \%$.

Tabel 3. Hasil Analisis Uji Regresi Linear Sederhana Dimensi-dimensi Konflik Peran Ganda terhadap Spiritualitas di Tempat Kerja

\begin{tabular}{cccccc}
\hline Dimensi konflik peran & \multicolumn{5}{c}{ Spiritualitas di Tempat Kerja } \\
\cline { 2 - 6 } ganda & $\mathrm{R}^{2}$ & $\mathrm{~F}$ & $\mathrm{t}$ & $\mathrm{Sig}$ & Beta \\
\hline Time based conflict & 0.068 & 28.77 & -5.364 & 0.000 & -0.261 \\
$\begin{array}{c}\text { Behavior based conflict } \\
\text { Strain based conflict }\end{array}$ & 0.05 & 20.65 & -4.545 & 0.000 & -0.223 \\
& 0.167 & 78.968 & -8.886 & 0.000 & -0.409 \\
\hline
\end{tabular}

\section{Pembahasan}

Hasil kategori konflik peran ganda para guru wanita tergolong rendah. Hal ini menggambarkan konflik peran akan permintaan energi, waktu dan perilaku dalam perannya di rumah dan di tempat kerja dapat diatasi dan berjalan beriringan. Keadaan ini dapat disebabkan karena para guru wanita menyeimbangkan antara kehidupan kerja dan di rumah. Beberapa sumber daya yang mendukung seseorang untuk menanggulangi tekanan konflik kehidupan kerja dan di rumah seperti pernikahan yang baik, waktu bebas, kesehatan diri, disiplin diri, asset finansial, dan keluarga yang selalu ada untuk membantu tugas-tugas (Hobfoll dalam Kossek \& Lee, 2017). Usia juga berkaitan dengan rendahnya konflik peran ganda yang dirasakan oleh para guru. Dalam penelitian ini sebagian besar usia guru wanita di rentang usia 40- 60 tahun. Seseorang yang semakin matang usia dalam karirnya akan menempatkan penekanan terhadap keseimbangan terhadap kehidupan kerja dan keluarga ketika menilai karirnya, oleh karena seseorang menempatkan prioritas lebih baik terhadap perannya dalam keluarga seiring usia, kepuasan karir pada orang yang berusia lebih tua tidak akan terlalu terpengaruhi oleh konflik peran ganda daripada individu yang berusia lebih muda 
(Gordon \& Berry dalam Mjoli, Dywili \& Dodd, 2013).

Hasil deksriptif spiritualitas di tempat kerja menunjukkan para guru wanita memiliki spiritualitas di tempat kerja tergolong tinggi. Hal ini berarti guru wanita mencari makna dan tujuan dari pekerjaannya, melibatkan diri dalam profesinya sebagai guru, sebagai bentuk ekspresi kebutuhan dalam diri (inner life) dengan melihat kebermanfaatan seorang guru kepada masyarakat (Mat, Romli, Mat, \& Noor, 2012). Penelitian spiritualitas di tempat kerja di Israel oleh Lazar, Davidovitch, dan Coren (2016) diperoleh hasil bahwa perempuan lebih merasa panggilan dalam pekerjaannya dibandingkan pria, begitupula dengan aspek engaging work dan mystical experience pada perempuan. Pada wanita, mereka memandang bahwa panggilan sebagai pengajar adalah tanggungjawab transendental dan harus bermanfaat untuk masyarakat. Dalam hal ini dapat diartikan guru wanita mengatribusikan profesinya sebagai guru sebagai panggilan yang kuat. Beberapa penelitian di sekolah di Malaysia diketahui spiritualitas di tempat kerja berkontribusi terhadap kepemimpinan efektif, kepuasan kerja dan komitmen. Spiritualitas di tempat kerja juga membuat guru ingin memberikan usaha lebih dalam pekerjaannya (Ghani, Nasie, \& Intsar, 2009; Diana \& Rafaie, 2005 dalam Mat et al., 2012).

Sesuai dengan hipotesis penelitian, ditemukan konflik peran ganda berperan negative terhadap spiritualitas di tempat kerja. Semakin tinggi skor konflik peran ganda guru wanita, maka semakin rendah spiritualitas di tempat kerja dan sebaliknya. Acker (dalam Cinamon \& Rich, 2005) menyatakan bahwa menjadi guru sekaligus ibu tidaklah nyaman karena guru wanita harus menjalani tiga tugas yaitu mengajar, pekerjaan rumah tangga dan pengasuhan anak. Dalam menjalankan profesi sebagai guru, munculnya konflik peran di dalam ranah keluarga dan pekerjaan disebabkan karena tuntutan ranah yang satu dengan lainnya. Individu memiliki keterbatasan waktu dan energi sehingga memunculkan konflik antar peran dan beban peran yang berat. Implikasi konflik peran ganda juga terjadi pada profesi guru sebagaimana pekerjaan non tradisional lainnya. Bruck et al. (dalam Cinamon \& Rich, 2005) mengemukakan guru dengan konflik kerja-keluarga akan mengalami peningkatan dalam absensi kerja, keterlambatan, performansi hasil kerja yang baru, ketidak- puasan kerja dan intensi untuk pindah kerja. Guru wanita yang mengalami konflik peran ganda yang tinggi, mempengaruhi spirtualiasnya di tempat kerja mereka yang mana mereka akan merasa sulit untuk memaknai pekerjaannya, melaksanakan panggilannya sebagai seorang guru yang akhirnya berakibat pada menurunnya perilaku keterlibatan kerja. Sebaliknya, seorang guru wanita dengan konflik peran ganda rendah akan mampu menjalankan perannya sebagai guru di sekolah, memaknai pekerjaannya tidak sekedar mengajar tetapi terlibat dalam membangun karakter masa depan siswa. Sebagaimana Milliman et. al (2003), mengemukakan orang-orang dengan spiritualitas memiliki keterhubungan (connectedness) yang semakin tinggi akan menjadi individu yang lebih positif dan mencapai tujuan organisasi. Penelitian yang dilakukan oleh Liang et. al (2017), spiritualitas di tempat kerja pada guru-guru di Taiwan, aspek makna pekerjaan, perasaan bagian dari komunitas dan indentifikasi dengan organisasi membuat mereka memiliki perasaan memiliki pekerjaan yang bermakna, bagian dari komunitas dan berkontribusi terhadap kesejahteraan psikologis.

Analisa dari dimensi-dimensi konflik peran ganda terhadap spiritualitas di tempat kerja. Pertama, strain based conflict yang memiliki pengaruh signifikan terhadap spiritualitas di tempat kerja sebesar $16.7 \%$. Hal ini menunjukkan guru wanita menghadapi tuntutan psikologis dan ketegangan psikologis akibat berbagai tuntutan di kedua peran yang mempengaruhi spiritualitasnya di tempat kerja. Tekanan psikologis yang terjadi di tempat kerja dapat mempengaruhi peran guru sebagai seorang ibu dan istri terhadap keluarganya di rumah. Seseorang yang mengalami tekanan atau stress dalam waktu yang lama karena work family conflict akan mengalami kelelahan emosional dan mengakibatkan burnout (Mete, Unal, Bilen, 2014). Strain based conflict dalam penelitian ini ditemukan paling memiliki pengaruh terhadap spiritualitas di tempat kerja. Dijelaskan dalam penelitian sebelumnya strain based conflict juga paling berpengaruh terhadap stress dan menjadi menyalahkan pekerjaannya (Lambert, Hogan \& Ventura, 2006). Penelitian terhadap guru di Israel ditemukan ada tiga profil dalam menjalankan peran di tempat kerja dan keluarga: guru-guru yang memusatkan pentingnya peran dalam keluarga, di tempat kerja dan keduanya. Hal 
ini tergantung pada sikap individu apakah memiliki orientasi terhadap keluarga atau tempat kerja yang lebih kuat dan adapula yang menempatkan nilai yang kuat untuk kedua domain (Cinamon \& Rich, 2005).

Kedua, behavior based conflict diketahui berpengaruh negatif terhadap spiritualitas di tempat kerja dengan kontribusi sebesar $5 \%$ dan sisanya dipengaruhi oleh faktor-faktor lain. Work family conflict terkait dengan konflik peran, Erdamar dan Demirel (2014) menemukan masalah yang paling banyak dihadapi guru adalah masalah di kehidupan kerja yang membuat mereka merasa stress dan cemas di rumah. Lambert, Hogan dan Ventura (2006) menemukan bahwa karyawan yang mengalami tingkat behavior based conflict, menyadari peran di pekerjaannya yang tidak tepat terbawa ke rumah, cenderung akan menyalahkan pekerjaannya karena menyebabkan konflik muncul. Spiritualitas di tempat kerja digambarkan sebagai perasaan terhubung dengan pekerjaan, menerima dan melihat tujuan dari pekerjaan yang berintegrasi dengan nilai-nilai personal (Afsar \& Rehman, 2015). Ketika guru wanita merasakan konflik peran yang mengganggu dapat mempengaruhi spiritualitasnya di tempat kerja.

Ketiga, dimensi time based conflict dengan kontribusi $6,8 \%$, situasi yang mana waktu dikorbankan untuk sebuah peran sehingga sulit untuk memenuhi tugas-tugas di peran lainnya. Guru wanita dihadapkan pada situasi tertekan untuk memenuhi peran di keluarga dan profesionalitasnya, tugas pekerjaan mengajar anak-anak menyebabkan berkurangnya energi untuk merawat anak sendiri dan menjadi guru yang baik untuk anak (Claesson \& Brice dalam Cinnamon \& Rich, 2005). Ketika guru menghadapi konflik waktu yang harus diberikan untuk menjalankan peran-perannya akan mempengaruhi bagaimana guru menyeimbangkan kehidupan dalam dan luar dirinya agar tetap sehat dan jauh dari burnout karena guru harus dapat mengikuti job demand dan perubahanperubahan yang cepat di dunia pendidikan (Mat, et. al, 2012). Spiritualitas di tempat kerja merupakan bagian dari inner life (dalam diri) seseorang yang mencakup harapan dan kesadaran akan nilai-nilai personal individu serta keterhubungannya dengan dunia yang diekspresikan dengan bekerja.

Keterbatasan dalam penelitian ini meliputi konsep peran ganda yang diukur dalam penelitian adalah konflik pekerjaan terhadap keluarga (work-family conflict), akan tetapi dapat pula terjadi adanya konflik keluarga yang mempengarui peran di pekerjaan guru (family-work conflict) yang berpengaruh terhadap spiritualitas di tempat kerja yang tidak diukur dalam penelitian ini. Penelitian ini juga terbatas pada fenomena spiritualitas kerja yang terjadi pada profesi guru wanita.

\section{Kesimpulan}

Dalam penelitian data disimpulkan adanya hubungan antara konflik peran ganda dengan spiritualitas di tempat kerja pada guru wanita. Konflik peran yang dialami di tempat kerja dan keluarga pada guru tergolong rendah dan spiritualitas di tempat kerja tergolong tinggi. Para guru wanita yang mampu menyeimbangkan konflik peran dengan baik, kesadaran spiritualitas akan dapat memaknai pekerjaannya sebagai guru, berhubungan dan menjadi bagian dari komunitasnya.

Ditinjau dari keterbatasan penelitian diharapkan penelitian selanjutnya mengkaji fenomena spiritualitas di tempat kerja dengan responden dengan profesi atau bidang pekerjaan yang berbeda. Peneliti selanjutnya yang tertarik dengan topik serupa diharapkan mengembangkan kembali alat ukur konflik peran ganda dengan menambahkan butirbutir yang mengukur family-work conflict. Selain itu, spiritualitas di tempat kerja karena alat ukur dalam penelitian ini disusun sendiri oleh peneliti yang reliabilitasnya perlu diuji kembali di penelitian-penelitian berikutnya.

\section{Daftar Pustaka}

Aboobaker, N., Edward, M., \& Zakkariya, K. A. (2019). Workplace spirituality, workfamily conflict and intention to stay: An intrinsic motivational perspective among teachers. Journal of Applied Research in Higher Education, Vol. ahead-ofprint No. ahead-of-print. doi: 10.1108/ JARHE-07-2018-0160

Afsar, B., \& Rehman, M. (2015). The relationship between workplace spirituality and innovative work behavior: The mediating role of perceived personorganization fit. Journal of Management, Spirituality \& Religion, 12(4), 329-353. doi:10.1080/14766086.2015.1060515

Ahmadi, S., Nami, Y., \& Barvarz, R. (2013). The relationship between spirituality in the workplace and Organizational Citizenship Behavior. Procedia Social 
and Behavioral Science, 114, 262-264.

Almasitoh, U. H. (2011). Stress kerja ditinjau dari konflik peran ganda dan dukungan sosial pada perawat. Jurnal Psikologi Islam. Retrieved from http:// psikologi.uin-malang.ac.id/wp-content/ uploads/2014/03/Stres-KerjaDitinjau-DariKonflik-Peran-Ganda-Dan-DukunganSosial-PadaPerawat.pdf

Apollo \& Cahyadi, A. (2012). Konflik peran ganda perempuan menikah yang bekerja ditinjau dari dukungan sosial keluarga dan penyesuaian diri. Widya Warta, 2(1), 254 - 271. Retrieved from http://download.portalgaruda.org/article. php?article $=116765 \& \mathrm{val}=5324$

Ashar and Lane-Maher (2004). Success and Spirituality in the New Business Paradigm. Journal Of Management Inquiry, 13 (3), 249-260.

Ashmos, D. P., \& Duchon, D. (2000). Spirituality at work: A Conceptualization and Measure. Journal of Management Inquiry, 9(2), 134-145.

Arifin, Z. (2013). Menjadi guru profesional (isu dan tantangan masa depan). Edutech, 1, (3), 132-155. Retrieved from http:// ejournal.upi.edu/index.php/edutech/article/ view/3225/2239

Beban kerja guru tidak sama dengan beban kerja pegawai kantor. (2016, 27 April). Pgri-jateng. Retrieved from http://pgrijateng.info/archive/read/72/bebankerjaguru-tidak-sama-dengan-beban-kerjapegawai-kantor

Butts, D.(1999). Spiritualityatwork: anoverview. Journal of Organizational Change Management, 12(4), pp.328-332, https:// doi.org/10.1108/09534819910282162

Charkhabi, M., Sartori, R., Ceschi, A. (2016). Work-family conflict based on strain: The most hazardous type of conflict in Iranian hospital nurses. SA Journal of Industrial Psychology, 42(1), 1-10.

Cinamon, R. G., \& Rich, Y. (2005). Workfamily conflict among female teachers. Teaching and Teacher Education, 21, 365-378.

Duchon, D., \& Plowman, D. A. (2005). Nurturing the spirit at work: Impact on work unit performance. The Leadership Quarterly, 16, 807-833.

Erdamar, G., \& Demirel, H.(2014). Investigation of work-family, family-work conflict of the teachers. Procedia Social and Behaivoral Sciences, 116, 4919-4924. doi: 10.1016/j.sbspro.2014.01.1050

Fields, D. L. (2002). Taking the measurement of work. Retrieved from http://gen.lib. rus.ec/book/index.p?md5=294734CD3 3C6652914DB6D1 AB8745D25

Imran, S. (2015, Januari 5). Beberapa saran solusi dalam membantu mengatasi hambatankemampuan intelektual siswa. IImu-pendidikan. Retrieved from http:// ilmu-pendidikan.net/siswa/saran-solusimembantu-mengatasikemampuanintelektual-siswa Iskandar. (2013, Desember 8).

Iskandar. (2013, Desember 8). Jumlah guru di Indonesia berlebih. Solopos. Retrieved from http://www.solopos.com/2013/12/08/ jumlah-guru-di-indonesiaberlebih-472205.

Esy. (2015, Januari 1). 40 persen PNS di Indonesia adalah guru. Jpnn. Retrieved from http://www.jpnn.com/news/40-persenpns-di-indonesia-adalah-guru.

Fields, D. L. (2002). Taking the measurement of work. Retrieved from http://gen.lib. rus.ec/book/index.p?md5=294734CD3 3C6652914DB6D1 AB8745D25

Greenhaus, J. H., \& Beutell, N. J. (1985).

Sources of conflict between work and family roles. Academy of Management Review, 10(1), 76-88

Julianty, E. \& Prasetya, B. E. A. (2016). Hubungan antara dukungan sosial suami dengan konflik peran ganda pada guru wanita di Kabupaten Halmahera Barat. Jurnal Psikologi Perseptual, 1(1), 27-39. Retrieved from http://jurnal. umk.ac.id/index.php/perseptual/article/ view/1077

Ke, J. , Zhang, F. , Yan, X. and Fu, Y. (2017) The Effect of University Teachers' Workplace Spirituality on Employee Engagement: Professional Commitment as Mediator. Creative Education, 8, 2147-2154. doi: 10.4236/ce.2017.813145.

Kementerian Pendidikan dan Kebudayaan. (2017). Data guru. Retrieved from http:// dapo.dikdasmen.kemdikbud.go.id/ guru/1/010000

Kinjerski, V. (2013). The spirit at work scale: Developing and validating a measure of individual spirituality at work. In J. Neal (ed.), Handbook of Faith and Spirituality in the Workplace: Emerging Research and Practice (pp 363-402). New York, NY: Springer Science.

Kossek, E. E., \& Lee, K. H. (2017). Work- family conflict and work-life conflict. Oxford Research Encyclopedia of Business and Management. doi: 10.1093/ acrefore/9780190224851.013.52 
Lambert, E. G., Hogan, N. L., Camp, S. D., \& Ventura, L. A. (2006). The impact of work-family conflict on correctional staff. Criminology \& Criminal Justice, 6(4), 37187. doi:10.1177/1748895806068572

Lazar, A., Davidovitch, N., \& Coren, G. (2016). Gender differences in calling and work spirituality among Israeli academic faulty. Journal of International Education Research, 12(3), 87-98.

Liang, J. P., Peng, L. X., Zhao, S. J., \& Wu, H. T. (2017). Relationship among workplace spirituality, meaning life, and psychological well being of teachers. Universal Journal of Educational Research 5(6), 1008- 1013.

Mat, N., Romli, R., Mat, N., \& Noor, N. M. (2012). Modelling workplace spirituality and teaching effectiveness for academician in Malaysia. International Journal of Business and Management Studies, 4(1), 157-164.

Mete, M., Unal, O. F., \& Bilen, A. (2014). Impact of work-family conflict and burnout on performance of Accounting professionals. Procedia Social and behavioral Sciences, 131, 264-270. doi: 10.1016/j.sbspro.2014.04.115

Michel, J. S., Kotrba, L. M., Mitchelson, J. K., Clark, M. A., \& Baltes, B. B. (2011). Antecedents of work-family conflict: A meta-analytic review. Journal of Organizational Behavior, 32(5), 689725.

Milliman, J., Czaplewski, A. J., \& Ferguson, J. (2003). Workplace spirituality and employee work attitudes: An exploratory empirical assessment. Journal of Organizational Change Management, 16(4), 426-447.

Mjoli, T., Dywili, M., \& Dodd, N. (2013). Demographic determinants of workfamily conflict among female factory workers in South Africa. Journal of Economics, Business and Management, 1(1), 39-41.

Petchsawang, P., \& Duchon, D. (2009). Measuring workplace spirituality in an Asian context. Human Resource Development International, 12(4), 459468.

Randy, A. (2017, Januari 25). Penyebaran guru tak merata, paling banyak di Jakarta. Otonomi. Retrieved from https:// www.otonomi.co.id/news/iniperbandinganjumlah-guru-di-jakarta-dan-daerah- 170125y.html

Richter, A., Schraml, K., \& Leineweber, C. (2014). Work-family conflict, emotional exhaustion and performance-based self esteem: Reciprocal relationships. International Archives of Occupational and Environmental Health, 88, 101-112. doi: 10.1007/s00420-014-0941-x

Sabuhari, R. \& Soleman, M.M. (2016). Pengaruh work family conflict terhadap stress kerja (studi kasus pada ibu yang bekerja sebagai guru di Kota Ternate). Jurnal Penelitian Humano, 7(2), 113125. Retrieved from http://ejournal. unkhair.ac.id/index.php/humano/article/ view/320

Stephens, G. K., \& Sommer, S. M. (1996). The measurement of work to family conflict. Retrieved from http://epm.sagepub.com/ content/56/3/475

Tanudjaja, R. M. (2013). Hubungan antara konflik keluarga-kerja, makna kerja sebagai panggilan, dan persepsi terhadap dukungan organisasional dengan keterikatan kerja pada guru. Jurnal IImiah Mahasiswa Universitas Surabaya, 2(1), 1-10. Retrieved from https://media.neliti.com/media/publications/ 186050-ID-hubungan-antarakonflikkeluarga-kerja-m.pdf 78

Yogatama, L. A., \& Widyarini, N. (2015). Kajian spiritualitas di tempat kerja pada konteks organisasi bisnis. Jurnal Psikologi, 42(1). 1-14. 